\title{
ASSESSMENT OF THE LOCAL STATE ADMINISTRATION PREPAREDNESS LEVEL ON THE SOLUTION OF CRISIS EVENTS
}

\author{
Daniel Brezina $^{1}$, Michal Titko ${ }^{2}$
}

\begin{abstract}
The preparedness of the state and local administration to deal with different crisis events is a prerequisite for a functioning crisis management system in each country. However, the level of preparedness varies across the state from region to region, which can be caused by various factors. In recent years, in addition to the well-prepared crisis management system, the development of a society that is resilient to crisis events and increasingly engaged into the prevention and crisis events solution, has become an important objective of crisis management institutions worldwide. These efforts are carried out mostly at the local level. The aim of the article is therefore to investigate first and foremost the preparedness of the local government to deal with crisis events and consequently its ability to integrate community into this process. Based on the analysis of the crisis management system of the district Čadca, Slovakia, the problems, challenges as well as positive trends within the preparation processes and community integration are identified and discussed.
\end{abstract}

JEL Classification Numbers: D73, H12, K32, DOI: 10.12955/cbup.v7.1390

Keywords: crisis events, crisis management, preparedness, local state administration, Čadca District Office

\section{Introduction}

Local government authorities (primarily district offices) manage several sections of the state administration, including the crisis management section. In this section's district offices, crisis management departments in particular, create the conditions for coordinating and controlling activities related to the preparation and solution of crisis events (Ostrowska, 2014; Sullivan, 2010; Neubauerová 2010). It is done namely in the areas of (1) civil protection of the population and state management in crisis situations outside the time of war and ware state, (2) economic mobilization, and (3) defence of the state (Crisis Management Department, 2019).

From these areas, the article will focus on the first mentioned area (civil protection), because the increasing number and intensity (IPCC, 2014; WEF, 2019; Guo, 2018; Groenemeijer, 2016; Bouwer, 2011; Guba-Sapir, 2004; Luskova, 2015) of non-military crisis events such as disasters, man-made accidents, terrorist attacks, threats to public health, and their impacts on society (Šimák, 2016; Loveček, 2015), requires more emphasis on the preparedness of the crisis management system. The aim of the paper is therefore a comprehensive assessment of the level of preparedness of local government to deal with crisis phenomena. As a specific local state administration the Čadca District Office was chosen. The assessment of the preparedness level will be carried out on the basis of the law-set tasks analysis of the district office.

Current state analysis of the crisis management system on local government level - Case study: Čadca District Office

Within the crisis management system, District Offices are governed by laws and lower laws that create space for both (1) the appropriate preparation and implementation of preventive measures against the crisis events, and (2) an effective response to crises. These two areas are closely linked and treated by Act No. 42/1994 about civil protection. The local government's crisis management system should be prepared to address crisis events according to the following model (Figure 1).

A prerequisite for effective reaction to crisis events is the planning of the response and the elaborate preparation for these activities, including organizational, material and personnel supply (SanseverinoGodfrin, 2016). At the district office level, the activities related to the preparation enhancment of the crisis management system represent the following tasks (Act no. 42/1994):

1. elaborating the analysis of possible crisis event occurrences in the territorial district,

2. processing and updating of the population protection plan and its practicing,

3. managing and organizing preparation for civil protection,

4. organizing and carrying out preventive and educational activities in civil protection,

5. planning, declaring, managing and ensuring evacuation,

\footnotetext{
${ }^{1}$ University of Žilina, Faculty of Security Engineering, Department of Crisis Management, Žilina, Slovakia, daniel.brezina@fbi.uniza.sk

${ }^{2}$ University of Žilina, Faculty of Security Engineering, Department of Crisis Management, Žilina, Slovakia, michal.titko@fbi.uniza.sk
} 
6. managing and controlling civil protection material, providing civil protection units created for the needs of the territory with civil protection material.

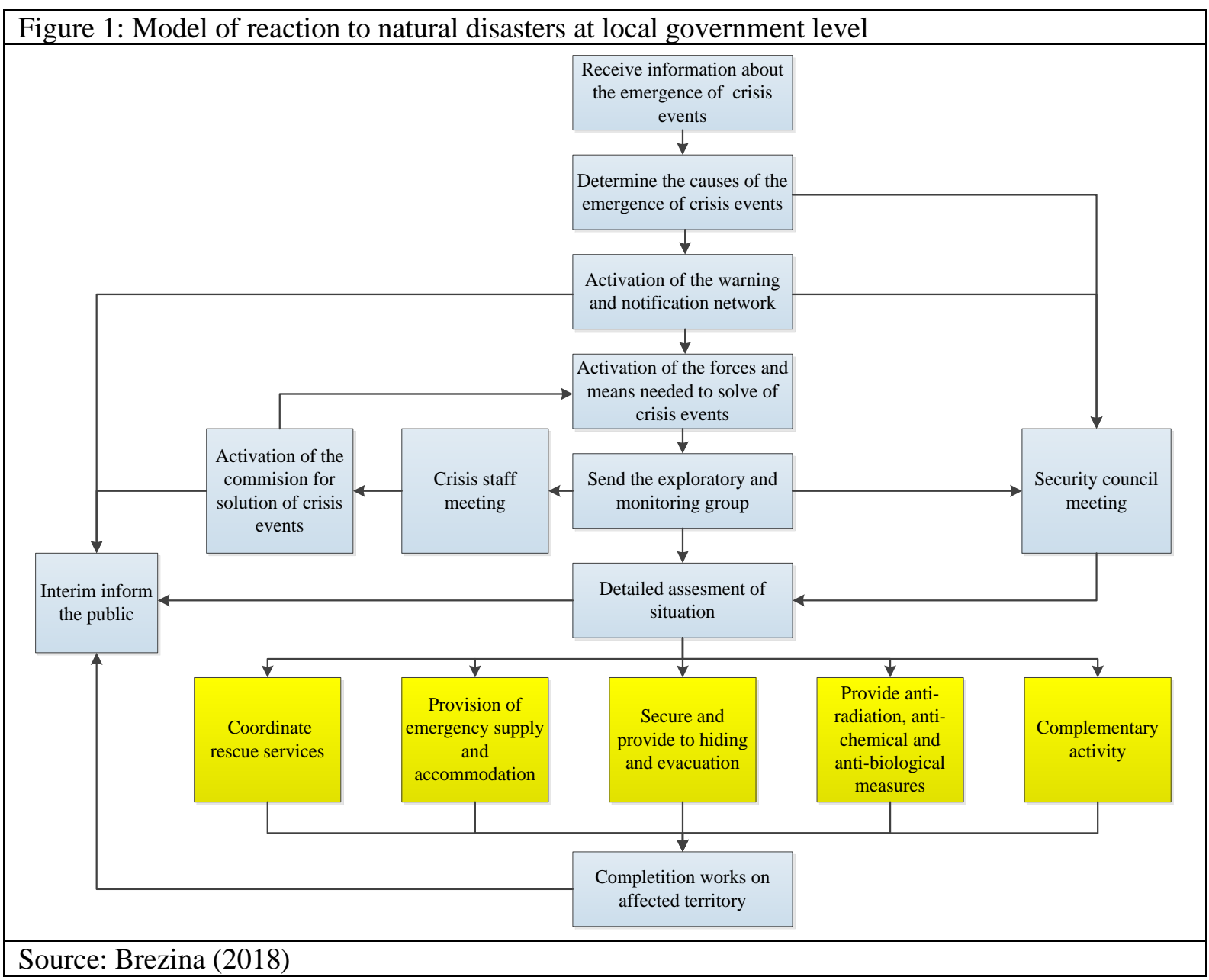

Figure 2: Number of crisis events by type and year of occurrence

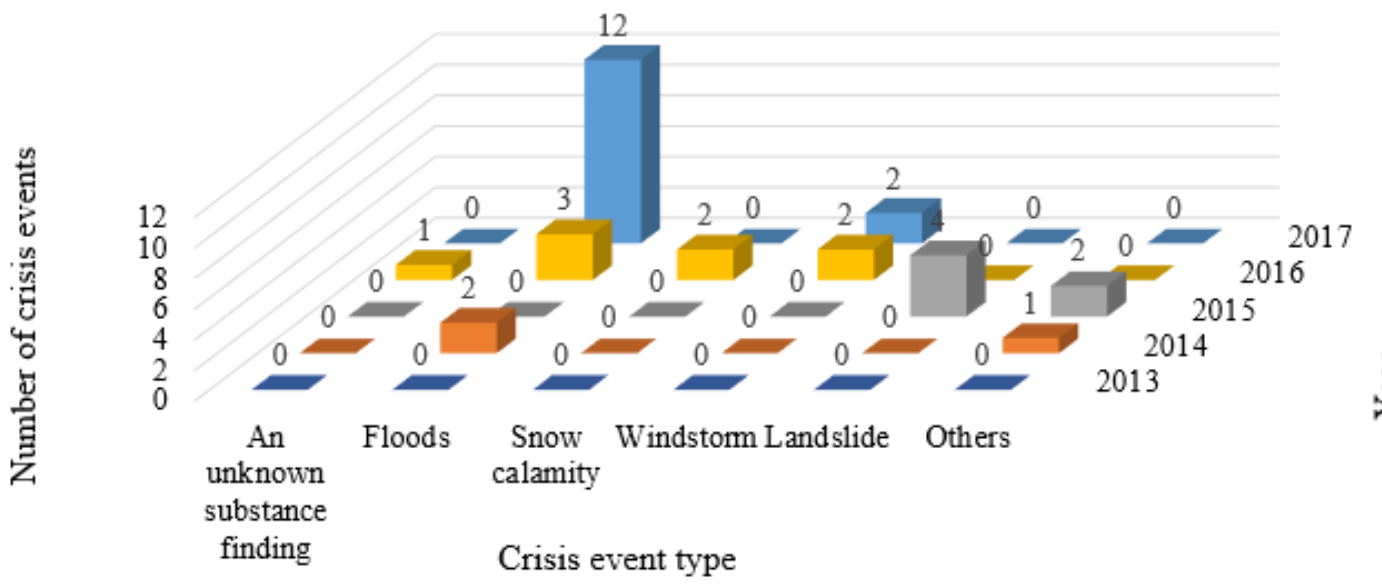

Source: Statistical evaluation of crisis events (2013-2017)

The following analytical section is excluded to the above-mentioned preparation activities only.

1. The Čadca District Office has prepared the document "Analysis of the Area of the Possible Crisis Events in the Territorial District of the Čadca District Office" (hereinafter "Analysis of Risks"). In the analysed area which is divided into smaller parts (26 parts in total) including municipalities, towns and city districts, the following crisis events are considered to be the most significant: snow calamities (occurring 23 times within the analysis), slope movements (7 times), water structure crash (6 times), 
floods (5 times), and accidents with hazardous substance leakage (1 time). This analysis does not fully correlate with the occurrence of crisis events in recent years (Figure 2). Therefore we believe it would be appropriate to include that fact into the analysis.

2. The Population Protection Plan is being implemented, but rather in an administrative form (paper/ electronically) than in practice. Its practice is minimized to the necessary minimum. The plan practice or exercises is primarily a matter of municipalities, so mayors are responsible for that. The Cadca District Office coordinates the creation of the Population Protection Plan and provides information for municipalities, if they are interested (Gonščák 2015).

3. The management and organization of preparation for civil protection can be divided into (1) preparation of civil protection units, (2) preparation of selected enterprises and their employees, and (3) preparation of the other population.

Civil protection units, evacuation and emergency accommodation units in particular, are being prepared and trained regularly, but most recently they were trained in 2014. The preparation of selected enterprises and their employees is carried out according to the Population Protection Plan exercise schedule.

The preparation of the other population is carried out in conjunction with task 4 which includes preventive and educational activities in civil protection. Therefore they will be jointly explained in task 4.

4. The population preparation for crisis events and its education is the responsibility of individual municipalities, which are located in the territorial district of the Čadca District Office. Within these tasks an electronic form of information mediation, e.g. websites and TV channels of individual municipalities, is prevalent. The Čadca District Office performs preparation for self-protection and mutual assistance in selected institutions that fall under the Higher Territorial Unit (HTR) - Žilina Region. Education and preparation is mainly done in the form of lectures, at various primary and secondary schools, retirement homes, libraries, etc. The participants are informed about the facts from the document "Analysis of Risks", especially about the possible risks of crisis events and warning signals in the case of an emergency. In addition to lectures, various brochures containing the necessary information for the public are also published. An interesting activity is the student's competition where students can test their knowledge about civil protection issues (Gonščák 2017).

5. The Čadca District Office plans and provides evacuation in cases where there is an assumption of a crisis event which effects several municipalities' territory at once. According to the conclusions of the "Analysis of Risks" and consistent with the Decree of the Ministry of the Interior of the Slovak Republic no. 328/2012 Coll. about evacuation details, the Čadca District Office plans and provides evacuation only from the area endangered by the Nová Bystrica water structure, namely for the municipalities Nová Bystrica, Stará Bystrica, Klubina, Zborov nad Bystricou, Krásno nad Kysucou and Dunajov. The evacuation plan and its necessary parts (evacuation routes, evacuation accommodation for selected municipalities with limit numbers, other accommodation options, contracts with carriers, and also forces and means to ensure evacuation) have been processed by the Čadca District Office. Evacuation is not planned for other crisis events that may be expected to affect several municipalities. The reasons are: (1) the place of origin cannot be predetermined (transport of dangerous substances); (2) a small number of vulnerable populations (snow calamities, landslides, storms, hailstorms; (3) the extent of the event and the unpredictability of its consequences (seismic activity); (4) unpredictability of the attack site and the extent of the event (terrorist attack). Some events are excluded because: (1) there is no object that manufactures, stores and manipulates hazardous substances (leakage of a hazardous substance); (2) there is no widespread flooding of a larger area (floods).

6. In order to be capable of action, the Čadca District Office provides the civil protection units (44 civil protection units) with material and any necessary supplies. It also provides supplies for rescue forces to deal with crisis events if needed. This includes own resources as well as resources held by companies and persons located in the territorial district of the Čadca District Office. Individual municipalities, according to the instructions of the Čadca District Office, carry out a physical inventory of civil protection material intended for the population protection (protective masks, children's protective bags, dosimeters, etc.) and provide the results to the Čadca District Office. If the means of individual protection are not in good technical condition and some of them are unusable, it is necessary to replace 
them with new ones and modern ones that would meet the requirements for the proper population protection.

In addition to the above mentioned tasks, the district office carries out also other tasks, which include inspection activities, application of construction requirements, aftermath assessments and rescue works assessments, etc. However, in our opinion, these are not priority tasks related to the preparation for civil protection. A similarly different category are the already mentioned tasks within the response phase to the crisis event, which is out of the scope of this paper.

\section{Problems and challenges within preparation processes on the solution of crisis events}

In the crisis management system at the local level, the employees face different types of problems and various challenges. They can vary from district to district, but there are common issues. The following results (problems and challenges) for the Čadca District Office were obtained on the basis of analysis of performed tasks and personal interviews in this district. We will proceed from more specific issues within individual tasks to complex issues that are related to the crisis management system at the local level.

The update of the document "Analysis of Risks" is being carried out continuously, but only according to specified instructions and deadlines within the law. It would be appropriate to implement this update as soon as the first changes in risk factors are observed. This problem is caused mainly by the insufficient personnel capacities of the crisis management department of the Čadca District Office.

As mentioned above, the creation and update of the "Population Protection Plan" is the responsibility of the Čadca District Office with the cooperation of municipalities and selected companies. The practice of its individual activities and tasks by the Čadca District Office is minimized to the necessary minimum and every extra practice activity is a result of the proactivity of individual municipalities only. The way of practicing the Population Protection Plan is not precisely and methodically determined, which is rather a systemic error than the error of the Čadca District Office. The last exercise, where only a small part of the tasks was practiced, took place in 2017. We argue, that it will be useful to more closely cooperate with municipality and company entities in the Čadca district.

The forms of civil protection preparation do not address target groups at a sufficient level. Children are paramount, which we perceive very positively, but also the adults should be our focus. The reason for this is that they will be the decision-makers and responsible for actions in the case of a crisis event. We also believe that in the preparation for self-protection and mutual assistance in selected institutions within the territorial jurisdiction of the Čadca District Office, it is necessary to expand the provided information on the possibilities of population individual protection, as well as on information on ways on how to deal with specific emergencies, including the principles of behaviour during emergency situations. Given the dynamics of the environment development, it would be appropriate to prepare the population and the civil protection units (most recently 2014) more frequently.

At the same time, the frequency of inspections by the Čadca District Office in municipalities, which are crucial for the population preparation could be higher, with a focus on the activities of the "Population Protection Plan" in particular.

An evacuation plan has been developed by the Čadca District Office only for the case of the Nová Bystrica water reservoir accident. For other cases, especially in several areas where smaller floods occur (once every 10 years on average), there is a lack of similar plans or models for larger floods (occurrence every 50-100 years on average), which would determine the optimal evacuation deployment. The Čadca District Office relies on the operative solution of the given event and in some cases the justification for "not planning" an evacuation is quite questionable. The issue of the needs for large scale floods deserves more attention, as their occurrence, with increasing weather fluctuations and uncontrollable human interventions into the nature (deforestation) in Čadca district, is also more likely to occur.

An inconspicuous problem that does not fall under any activity defined by law is the transfer of competencies when an employee quits their job or retires. This problem is related to the fact that the whole system is maybe set up correctly, but if the responsible manager is not sufficiently prepared and familiar with his or her competences, a problem may arise in this change of employee's period. This problem has been identified at the Čadca District Office. The issue is mainly a restricted office budget and a small number of employees in this sector. 
The legal environment in crisis management in the conditions of the Slovak Republic is one of the more complex problems. According to Benedik (2018), terminological inconsistencies and ambiguity in legislation cause in practice a number of problems and barriers. This was confirmed also by crisis management staff of the Čadca District Office after personal interviews. The problems are mainly related to the evaluation of the situation, application of law into practice, number of regulations and defined competencies, etc. Frequent adjustments and amendments to the legislation are not good for the quality of the crisis management system.

The next issue is the determination of competences of local government in relation to individual municipalities. If the towns and villages declare a crisis events, the local government does not have the authority to recall it. The mayors have this authority only. The obligation to recall a crisis events, depends on the exclusion of the reasons for its declaration. This is another issue that is not addressed in the legislation.

\section{Conclusion}

The effectiveness of an emergency response is directly proportional to thorough and sophisticated prevention, including the preparation of the local government and the population to deal with the consequences of a crisis event. Ensuring and improving the quality of crisis management at the local level requires strong horizontal and vertical relations and links. The local government represents a very important position in the field of the crisis management system, within preparation and the solution of crisis events in particular. It is necessary to emphasize the creation of the most effective environment for the cooperation of all subjects involved in these processes.

Based on the analysis, it can be said that the Čadca District Office has set up a comprehensive and complex crisis management system. The decisive issue is the passivity of crisis management institutions and employees. They lack proactivity. Basically, crisis managers and employees of public administration do nothing more than what is imposes by law. It is true that the low number of crisis management employees at the local level gives very little scope for such "extra" activities. It seems to be a systematic problem, not a problem at the local level. According to the current conditions, the Čadca District Office is very well prepared for the solution of crisis events. There is still a need for functional staffing, efficient technical resources and sophisticated procedures to response all crisis events, including less likely events.

\section{Acknowledgements}

Publication of this paper was supported by the Scientific Grant Agency of the Ministry of Education, Science, Research and Sport of the Slovak Republic - VEGA No. 1/0805/18 "Establishing the principles and sequence of steps to measure the awareness and preparedness of the population to the risks of natural disasters and institutional grant project" and KEGA No. 030ŽU-4/2018 "Research of Risk Management in Enterprises in Slovakia to create a new study program Risk Management for the FBI University of Žilina".

\section{References}

Act No. 42/1994 on Civil Protection.

Benedik, V. (2018). Zabezpečenie ochrany zdravia fyzickej osoby na území Slovenskej republiky [Ensuring the protection of individuals in the territory of the Slovak Republic]. In: Riešenie krízových situácií v špecifickom prostredí. Žilina. University of Žilina. s. 31-41. ISBN 978-80-554-1439-3.

Bouwer, L.M. (2011). Have Disaster Losses Increased Due to Anthropogenic Climate Change? In: Bulletin of the American Meteorological Society. DOI: http://dx.doi.org/10.1175/2010BAMS3092.1

Brezina, D., \& Šimák, L. (2018). Proposal for a model of effective reaction to natural disasters in the territory of Slovakia. In: CBU International Conference Proceedings 2018 : Innovations in Science and Education. - ISSN 1805-9961. - Prague: CBU Research Institute s.r.o., 2018. - ISBN 978-80-270-5037-6. - S. 1017-1023. Available at: https://journals.cz/index.php/CBUIC/article/view/1288

Crisis Management Department. (2019). Content of the activities of the department of crisis management. Available at: https://www.minv.sk/swift_data/source/miestna_statna_sprava/okres_cadca/odbor_okr/cinnosti_OKR.pdf

Decree of the Ministry of the Interior of the Slovak Republic no. 523/2006 Coll. on Details to Rescue Services Secure Organizing of Civil Protection Forces.

Decree of the Ministry of the Interior of the Slovak Republic no. 328/2012 Coll. on Evacuation Details.

Gonščák, R (2015). Population Protection Plan. No. 502/8. 
Gonščák, R., \& Sedláček, P. (2017). Analysis of the Area of the Possible Crisis Events in the Territorial District of the Čadca District Office. No. 502/2-25. 32 p.

Groenemeijer, P., et al. (2016). RAIN Project. D2.5 Present and Future Probability of Meteorological and Hydrological Hazards in Europe.

Guba-Sapir, D., Hargitt, D., \& Hoyois, P. (2004). Thirty years of natural disasters 1974 -2003: The numbers. Brussel: Louvain-la-Neuve, 190 pp. ISBN 2-930344-71-7.

Guo Y., Gasparrini A., Li S., Sera F., Vicedo-Cabrera A.M., de Sousa Zanotti Stagliorio Coelho M., et al. (2018) Quantifying excess deaths related to heatwaves under climate changes cenarios: A multicountry time series modelling study. PLoSMed 15(7):e1002629 DOI: https://doi.org/10.1371/journal.pmed.1002629.

IPCC - Intergovernmental Panel on Climate Change. (2014). Climate Change 2014: Synthesis Report. Contribution of Working Groups I, II and III to the Fifth Assessment Report of the Intergovernmental Panel on Climate Change [Core Writing Team, R.K. Pachauri and L.A. Meyer (eds.)]. IPCC, Geneva, Switzerland, 151 pp.

Loveček, T., Ristvej, J., Sventekova, E., Mika, V. T. \& Zagorecki, A. (2015). Currently Required Competencies of Crisis and Security Managers and New Tool for their Acquirement - the eSEC Portal. In: 13TH INTERNATIONAL CONFERENCE ON EMERGING ELEARNING TECHNOLOGIES AND APPLICATIONS (ICETA). The Amer Chamber of Commerce in the Slovak Republic; Elfa; TU; IEEE; Stu Fiit; Sanet; CTF atm; PPP; It Asociacia Slovenska; It News; EurActiv; PC revue; Education.sk; Infoware. p. 249-254. ISBN 978-1-4673-8534-3.

Luskova, M., Dvorak, Z., \& Leitner, B. (2015). Impact of Extreme Weather Events on Land Transport Infrastructure. Transport Means 2015. Transport Means -Proceedings of the International Conference. pp. 306-309.

Neubauerová, E., \& Dubrovina, N. 2010. Verejná správa v slovenskej republike -aktuálne problémy [Public administration in the Slovak Republic - current problems]. In: Veřejná správa. ISBN 978-80-7395-828-2.Ostrowska, M., 2014. Risk management in crisis situations [online]. Krakow. Andrzej Frycz Modrzewski Krakow University. Poland. Forum Scientiae Oeconomia. Volume 2. p. 76-84. [cit. 2018-08-01]. Available at: http://www.wsb.edu.pl/container/Wydawnictwo/Do\%20pobrania/6.-ostrowska.pdf

Sanseverino-Godfrin, V., 2016. The problems of the late implementation of the legal prevention measures for flood risk. p. 2. Flood risk 2016 - 3rd European Conference on Flood Risk Management. DOI: 10.1051/e3sconf/20160713010.

Sullivan, T. H. \& Häkkinene, T. M. 2011. Preparedness and Warning Systems for Populations with Special Needs: Ensuring Everyone Gets the Message (and Knows What To Do). Geotechnical and Geological Engineering. Volume 29. Springer Netherlands Publisher. p. 225-236. ISSN 0960-3182.

Ministry of the Interior of the Slovak Republic. Statistical evaluation of crisis events from 2013 to 2017.

WEF - World Economic Forum. (2019). The Global Risks. Report 2019. 14th Edition. Geneva, Switzerland, 114 pp. 